\title{
Destined for the downfall and rise of many in Israel': Luke 2:34b in patristic land modern) exegesis
}

J H Barkhuizen

University of Pretoria

\begin{abstract}
A close reading of both patristic and modern exegetes points towards the existence of two main schools of thought, and the aim of this short paper is to introduce the main proponents of each school, stating both the basic notion of each and the biblical evidence serving as the basis for their subsequent argumentation. The paper concludes with some suggestions for further discussion
\end{abstract}

What did Simeon mean when he referred to the child Jesus in Luke 2:34b, as the downfall and rise of many in Israel? A close reading of both patristic and modern exegetes points towards the existence of two main schools of thought ${ }^{1}$.

The prophecy of Simeon "has usually been interpreted as the fall of some and the rising of others, that is a process of self-judgement in which men determine the verdict to be passed on their lives, by the response they make to the coming of the Messiah' (Caird 1979:64). One very typical commentary within this school of thought is for example the following by Fritz Rienecker (1977:69):

Es zeugt von einem tiefen Blick des alten Simeon, dass er die Verheissung des Jesaja (Fap 8,13-15) in Christus sich erfüllen sieht. Alle müssen in Israel an Ihm vorbei und keiner kann Ihn unbeachtet lassen. Israel ist wie ein Strom, der sich an Christus, dem Felsen, brechen und zwiegeteilt weiterströmen wird. Dem einen zum Fall, dem andern zum Heil.

1 Among (Greek) patristic authors dealing with the interpretation of Simeon's prophecy the main figures are: Origen (hom 17:2-3 on Luke, ed Crouzel et alii); Basil the Great (Letter to Optimus, PG 32.964C-965A); Amphilochius (hom.2.8, ed Datema); Pseudo-Chrysostom (PG 50.810); PseudoAthanasius (PG 28.973-1000); Theodotus Ancyranus (PG 77. 1409B); Cyrillus Alexandrinus (PG 77.1048D); Timotheus Hier. (PG 86[1].245A-B); Sophronius (oratio iii.cap.iv.15, PG 87[3]) and Hesychius of Jerusalem (hom.1.7. and hom.2.9, od Aubineau). 
The basic notion of this, one may say, traditional interpretation, is that the expression

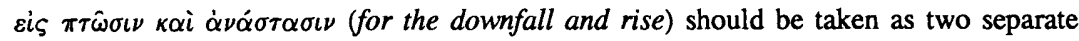
lexical units, referring to two separate sets of people (which Amphilochius in homily 2.8.211-212, ed Datema, defines specifically as the unbelieving Jews and the believing nations), with two separate sets of life-styles, resulting from two separate sets of choices or reactions: those who do not believe in Christ, continue in their disbelief, and are set for destruction; and those who come to believe in Christ, are not put to shame, and rise to a new life. A very curious position is taken in by PseudoAthanasius ( $P G$ 28.992C-D): there is no doubt that he also sees the expression as pointing to two separate lexical units, but his application is of a dogmatic, and not of a

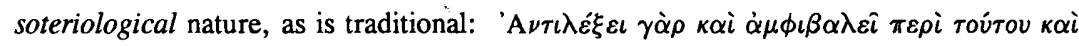

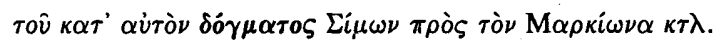

The basis for this interpretation, that is the biblical evidence put forward; is based on Isaiah 8:13-15 and Romans 9:33 on the one hand, and Isaiah 28:16 and 1 Peter 2:68 on the other hand - the two New Testament passages connecting the image of the stone and the rock from Isaiah with Christ, serving either as a stumbling block for those who are blind and cannot see in Christ the mystery of God, and are crushed by this stone, or as God's chosen cornerstone, on which men can build their lives by believing in Him.

The two main proponents of this school of thought, are Cyrillus of Alexandria (In occursum Domini nostri Jesu Christi, PG 77.1039-1050) and Hesychius of Jerusalem (In occursum Domini nostri Jesu Christi, homilies 1 and 2, ed Aubineau). The argumentation of Cyrillus of Alexandria can be divided into three phases:

* He begins with an allusion to Isaiah 28:16 and 1 Peter 2:6: God the Father has

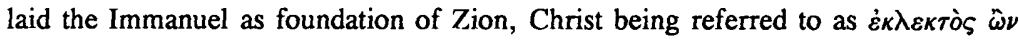
$\lambda i \theta 0 \varsigma \dot{\alpha} \kappa \rho \circ \gamma \omega \nu<\alpha i o \varsigma, \check{\varepsilon} \nu \tau \iota \mu \rho \varsigma$. This resulted in a twofold consequence: those who believed in Him, and were not put to shame, and those who did not believe (called $\check{\alpha} \pi \iota \sigma \tau o \iota ~ \kappa \alpha \grave{\imath} \dot{\alpha} \mu \alpha \theta \varepsilon i \varsigma)$, and could not see in Christ, the mystery of God's salvation, who consequently came to a fall and were crushed.

* He quotes Isaiah 8:14 (cf Rm 9:33; 1 Pt 2:7-8) directly, a passage in which God

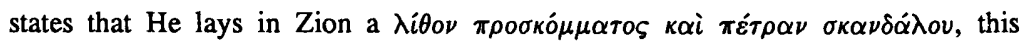
again resulting in a twofold consequence: the person who believes in Him will never be put to shame, but the stone will crush that person on whom it falls.

* Cyrillus again quotes from Isaiah 8:13-14, in which Israel is called upon to sanctify God, for then He will be their light (the reading in Migne; the LXX has 'fear'). A condition is added: if Israel will trust the Lord, He will be their 
sanctification, and not serve as $\lambda i \theta \omega \pi \rho \circ \sigma \kappa o ́ \mu \mu \alpha \tau o \varsigma$... où $\delta^{\prime} \dot{\omega} \varsigma \pi \dot{\varepsilon} \tau \rho \alpha \varsigma \pi \alpha \rho \alpha \pi-$ $\tau \dot{\omega} \mu \alpha \tau$. Cyrillus now draws a twofold conclusion: Israel did not sanctify the Lord, was not willing to trust in Him, stumbled consequently against the stone on account of their unbelief, was crushed and is now in a fallen position (note the perfect form $\pi \varepsilon \pi \tau \omega \kappa \varepsilon \nu)$. As antithesis to this Cyrillus immediately follows with the verb $\dot{\alpha} \nu \varepsilon \sigma \tau \eta \sigma \alpha \nu$, referring to the many who came to believe in $\mathrm{Him}$, who were transferred from the service of the law to that of the spirit, partaking in the divine nature after having been deemed worthy of becoming sons of God, and who thus are in constant expectation of obtaining the city of above, the kingdom of the heavens.

Hesychius of Jerusalem deals with this phrase in two homilies I.7.6-25 and II.9:

* In homily I Hesychius directly interprets the prophecy as follows: (Christ is destined) for a downfall of those who continue with their disbelief ( $\tau \hat{\omega} \nu \nu \dot{\varepsilon} \pi \iota \mu \varepsilon \nu \nu^{\nu}$ $\tau \omega \nu \tau \hat{\eta} \dot{\alpha} \pi \iota \tau \tau i \alpha)$, and for a rise of those who have moved from disbelief to faith. Alluding to Isaiah 28:16, 1 Peter 2:6,8, Rom 9:33 and Isaiah 8:14, he states that Christ was the stone of the foundation, but the blind were constantly stumbling against Him.

* In homily II.9, referring to Peter's citation of Isaiah 28:16, Hesychius actually quotes 1 Peter 2:7-8, and from this argues as follows:

Christ was destined for a downfall for the unbelievers, but for a rise for those who believe. Those who do not believe are defined as people who thought that they were standing upright because they had the law, but who by their disbelief came to a fall. Those who do believe are defined as people who were lying among the fallen ( $\mu \varepsilon \tau \alpha \xi \grave{v} \tau \hat{\omega} \nu \pi \varepsilon \pi \tau \omega \kappa o ́ \tau \omega \nu$ ) on account of their sins, but who raised themselves through their faith ( $\tau \hat{n}$

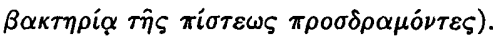

* But Hesychius also warns his audience: one should not attribute to Christ the fall of those who have fallen, although Christ is indeed the cause of their rising again.

* This is now illustrated by referrence to Judas and Peter, who both came to a fall, Judas by selling Him off to the Jewish leaders, and Peter by promising Him that he would die with Him, and not deny Him. Hesychius calls the betrayal of Judas a 
sin of the heart, but the denial of Peter a sin of the tongue. Therefore Peter, after he had fallen, rose again ( $\pi \varepsilon \sigma \grave{\omega} \nu \dot{\alpha} \nu \varepsilon \dot{\sigma} \sigma \eta)$ ), but Judas ended up with suicide (Tò

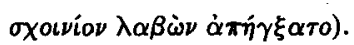

I will have to come back to this illustration, especially the example of Peter, in my discussion of the second school of thought.

Before I move on to the second school of thought regarding this verse from Luke, it is interesting to note from a rhetorical point of view, that the twofold nature of this phrase, according to the 'traditional' school of exegesis, has given some authors a much loved opportunity to express it by means of a series of antithetical statements. The following two examples may suffice:

Timotheus Hier. (PG 86 [1] 245A-B):

$\varepsilon i \varsigma \pi \tau \hat{\omega} \sigma \iota \nu \tau \hat{\omega} \nu \dot{\alpha} \pi i \sigma \tau \omega \nu, \varepsilon i \varsigma \dot{\alpha} \nu \dot{\alpha} \sigma \tau \alpha \sigma \nu \nu \tau \hat{\omega} \nu \pi \iota \sigma \tau \hat{\omega} \nu^{\circ}$

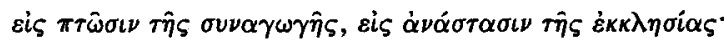

$\varepsilon i \varsigma \pi \tau \hat{\omega} \sigma \iota \nu \tau \hat{\omega} \nu \delta \alpha \iota \mu \dot{o} \nu \omega \nu, \varepsilon i \varsigma \dot{\alpha} \nu \dot{\alpha} \sigma \tau \alpha \sigma \nu \nu \tau \hat{\omega} \nu \dot{\alpha} \gamma i \omega \nu^{\circ}$

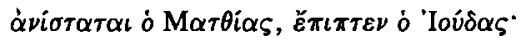

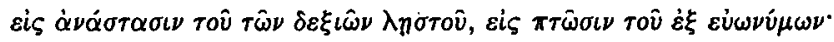

ö $\iota \dot{o} \mu \grave{\varepsilon} \nu \varepsilon \dot{v} \sigma \varepsilon \beta \varepsilon \hat{\varepsilon}, \dot{o} \delta \grave{\varepsilon} \dot{\varepsilon} \beta \lambda \alpha \sigma \phi \dot{\eta} \mu \varepsilon \iota$.

Sophronius (PG86 [1] 245A-B):

in ruinam servorum litterae, in resurrectionem filiorum gratiae;

in ruinam, legalem adhuc colentium vetustatem, in resurrectionem amantium evangeliam novitatem;

in ruinam gloriantium paternitate carnali Abrahae, in resurrectionem factorum Abrahae filiorum per fidem;

in ruinam indutorum prudentiam Adae veteris, in resurrectionem sapientium indumentum Adae novi;

in ruinam sapientium pulverea ac terrena, in resurrectionem cupientium excelsa atque coelestia.

In contrast to the more 'traditional' interpretation, the basic notion of a second group

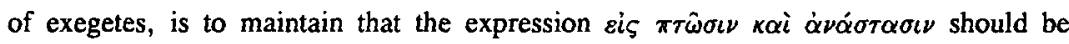
taken as a lexical unit, referring to the soteriological process in the life of one and the 
same person: 'But the natural interpretation of Simeon's words ... is that through the ministry of this one man Jesus the many in Israel will fall before they can rise to the promised glory ....' (Caird 1979:64).

Three important (Greek) fathers representing this point of view, are Origen, Basil the Great, and Romanos the Melodist. Most interesting is that all three authors refer at the outset of their argument, to the more 'traditional' interpretation, opposing it by an extensive form of 'polemical' exegesis, while Origen refers to the first interpretation as an elementary form of exegesis (Qui simpliciter exponit), defining his own as a more profound reading (Qui vero curiosus interpres est). The biblical evidence put forward by proponents of this school, in contrast to the former, varies from one to the other.

Origen (Homiliae in Lucam 17.2-3, ed Crouzel et alii) stresses the fact, that the expression must be viewed, as a single unit:

Videndum est itaque, ne forte Salvator non aliis atque aliis in ruinam venerit et in resurrectionem, sed eisdem et in ruinam et in resurrectionem venerit.

From this basis he argues as follows:

* For a person to fall implies first of all that he has stood upright;

* yet there is no such person to be found who was standing, and for whose fall Christ has become man;

* only he can rise who before has fallen;

* one should therefore first fall, and having fallen, should rise. Christ made him (i e Origen) fall down in order that he may rise again, and this downfall was more useful to him than when he appeared to be standing. He was 'standing' due to his sins at that time when he lived in sin, and because he was 'standing', supported as such by $\sin$, it was more useful for him to fall down and die for sin;

* thus Chris: first gives one the grace to fall down to enable one to rise again and

* in the light of this point of view, Origen points his audience to some practical and moral consequences: 
Ethnicus eras, cadat in te ethnicus:

diligebas scorta, primum in te scortator intereat;

peccator eras, cadat in te peccator, ut possis dehinc resurgere ...

These exhortations Origen in conclusion bases on $2 \mathrm{Tm}$ 2:11 and $\mathrm{Rm}$ 6:5.

si commortui sumus, et convivemus, et:

si conformes facti sumus mortis, conformes et resurrectionis erimus.

Basil the Great's explanation of this prophecy is found in his Letter to Optimus (Letter 260, PG 32.964C-965A):

* For Basil this expression does not mean that some fall and others rise, but that the worse in him comes to a downfall, while the better in him rises.

* This is explained by the statement that the Lord appeared in order to destroy the bodily passions, but causes the specific properties of the soul to rise. He bases his observation on Paul's statement: 'When I an weak, then I am strong', pointing out that Paul means that the same person is both weak and strong, weak in the flesh, but strong in the spirit. In the same way the Lord does not cause some to fall, and others to rise. For those who fall from their position, fall into the position where they once were.

* From this it is obvious that the unbeliever ( 0 o $\alpha \iota \sigma \tau o \varsigma)$ is never standing, but

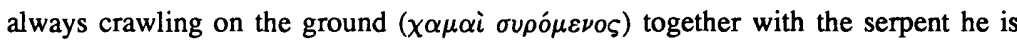
following! The unbeliever has therefore no position from which he falls, due to the fact that he has before been overturned through his disbelief ( $\delta i \grave{\alpha}$ rò $\pi \rho \circ \alpha \tau \alpha \beta \varepsilon \beta \lambda \hat{\eta} \sigma \theta \alpha \iota \tau \hat{n} \dot{\alpha} \pi \iota \sigma \tau i \underline{\alpha})$.

* The consequence is thus as follows: the first important thing is that one who is standing through his sin, should fall and die, then to live through righteousness and rise again - both being the result of our faith in Christ.

* Like Origen, Basil also concludes his interpretation with practical (moral) directives:

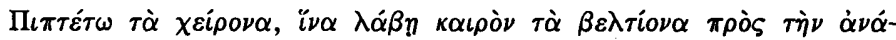
$\sigma \tau \alpha \sigma \iota \nu$.

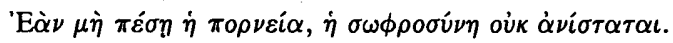

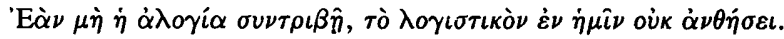


Romanos the Melodist explains this prophecy in the course of strophes 10-11 of hymn xiv (ed Grosdidier de Matons):

* In rephrasing Simeon's words as follows:

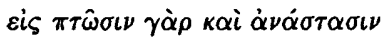

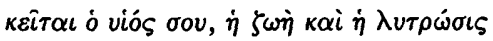

$\kappa \alpha \grave{i} \dot{\eta} \pi \dot{\alpha} \nu \tau \omega \nu \dot{\alpha} \nu \alpha \dot{\alpha} \sigma \tau \alpha \sigma \iota \varsigma$

It is obvious that he sees the expression as a single unit.

* He therefore states that it does not mean that some fall and others rise, basing his point of view on Ezechiel 18:32: God does not rejoice in the fall of men, and Christ has not become man with the pretext to bring those standing to a fall, but rather He hastens to raise those who are lying down, thus liberating his creation from death.

* 'Falling and rising again' is the very means, whereby the righteous attain to God's grace. Those who stand supported by sin, fall down and are counted as dead. But by righteousness and faith they rise again and live by grace. The passions of the body are destroyed, but the soul shimes forth, through virtues leading to a divine life.

* Romanos also concludes with some moral consequences:

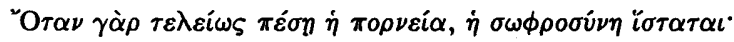

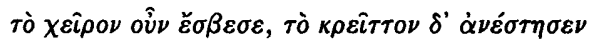

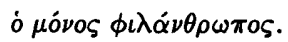

I have observed above that I would return to the example of Peter, referred to by Hesychius, and especially the phrase $\pi \varepsilon \sigma \grave{\omega} \nu \dot{\alpha} \nu \varepsilon \sigma \tau \eta$. Although Hesychius clearly represents the first or 'traditional' school of thought, this phrase reminds us of the very argument put forward, by the proponents of the second school of thought - in fact the very example of Peter (without being named specifically) is used by a modern exegete of this second point of view, Caird (1979:64) to prove his point: 'Even his best friends had to be humbled by failure, and then it was only because he had chosen to share their humiliation that they were able to rise at all'. 
Looking at these two sets of interpretation, the following could be put forward as basis for further discussion:

* The 'traditional' explanation which takes the phrase to point to two sets of people and their reaction towards Christ, is supported by the following considerations:

** The image of the rock/stone, taken from Isaiah, is interpreted by both Paul and Peter as referring to Christ, and the twofold reaction resulting from his epiphany.

** This is confirmed by many other situations recorded in the New Testament for example the events related by John 6 - the crowd, as well as many disciples, deciding to cease being his followers, because his words were too hard to digest - and even from among the intimate circle of disciples, one of them, Judas, chose another way. There is also the twofold reaction among the two robbers crucified with Him - one rejecting Him, the other accepting Him and remember it is only Luke who relates this twofold reaction on the part of the robbers (the other Gospels merely stating that two robbers were crucified with Him), while this very prophecy of Simeon is contained in only Luke's Gospel. Finally, Paul's argument in 2 Cor 2:15-16, also seems to support this point of view.

We are indeed the incense offered by Christ to God, both for those who are on the way to salvation, and for those who are on the way to perdition: to the latter it is a deadly fume that kills, to the former a vital fragrance that brings life -

** The argument that God does not cause the fall of any man, is taken out of proportion by the proponents of the second point of view: the mere epiphany of Christ resulted in a twofold reaction, which does not imply that Christ in person causes people to come to a fall. Hesychius, in fact, warns his audience against such a notion, although he represents the 'traditional' point of view!

* For the second point of view the following points could be raised in its favour: 
** Jesus explicitly states (Jn 12:22-26) that if one does not first lose his life for his sake, he will not rise to a new life (cf the image of the seed or corn falling into the soil). This is paralleled by another concept of Jesus, namely that in order to be his follower or disciple, one must first deny oneself before one can take up the cross and follow Christ (Lk 9:23-25). This, incidentally, was also true of Christ himself.

** One should also concede that no man is righteous, that every human being has 'fallen' through his sins, and that God does not cause the fall of any man.

\section{CONCLUSION}

The importance of having brought to light this twofold point of view or exegesis of Luke $2: 34 b$, is not to decide in the end which is the right one, and which the wrong one. Important is to point out how patristic exegesis in many ways, not only in this instance, has pointed the way for modern exegesis, escaping the statement so often expressed, that patristic exegesis is irrelevant or not important for a modern understanding of the Bible as God's Word today, for people of today. The study of patristic exegesis, and especially as this has been presented in patristic homilies, should therefore not be indulged in merely for the sake of one's own pleasure, or the pleasure of a few elect, but indeed also for its value for modern man and his understanding of the Word of God.

\section{Works consulted}

Aubineau, M 1979. Les homélies festales d'Hesychius de Jérusalem, Subsidia Hagiographica 59. Brussels.

Caird, G B 1979. Saint Luke. The Pelican New Testament Commentaries: Penguin Books.

Crouzel, H Fournier, F \& Périchon, P 1962. Origène. Homélies sur S.Luc. Paris: Les éditions du Cerf. (Sources chrétiennes 87.)

Datema, C 1978. Amphilochii Iconiensis Opera. Corpus Christianorum. Leuven: Brepols. (Series Graeca 3.)

Grosdidier de Matons, J 1965. Romanos le Mélode: Hymnes, vol II. Paris: Les éditions du Cerf. (Sources chrétiennes 110.)

Migne, J-P (ed) s a. PG: Patrologiae cursus completus (series Graeca). Paris: Migne. Rienecker, F (ed) 1977. Das Evangelium des Lukas. Wuppertal: R Brockhaus Verlag. (Wuppertaler Studienbibel.) 